\title{
Incidence of Lordosis Behavior in the Female Rat Following Removal of the Vomeronasal Organ
}

\author{
Toru R. SAITO, Ryoji HOKAO*, and Tomonori IMAMICHI* \\ The Institute of Environmental Toxicology, Suzuki-cho, Kodaira-shi, \\ Tokyo 187, Japan and *Imamichi Institute for Animal Reproduction, \\ Dejima-mura, Niihari-gun, Ibaraki 300-01.
}

(Received 14 July 1987/Accepted 2 September 1987)

\begin{abstract}
The lordosis behavior in female rats following removal of the vomeronasal organ (VNO) was observed for a period of $14 \mathrm{hrs}$ by means of a video camera monitor. Although the VNO-ablated female rats received a large number of mounts (96 to 204 times) by sexually active males, they showed only low scores ( 8 to 22 ) of lordosis quotients (number of lordosis behavior displayed/number of mounts $\times 100$ ). In contrast, sham-operated females showed the highest lordosis quotients of 100 as was expected.
\end{abstract}

The vomeronasal organ (VNO) in most mammalian species consists of a bilaterally paired tubular structure lying on either side at the base of the nasal septum. Receptor neurons within the VNO project to the accessory olfactory bulbs (AOB). The AOB, in turn, gives rise to afferent pathways which project to the corticomedial amygdala, and from there to the medial preoptic area and the ventromedial nucleus of the hypothalamus [1]. Saito and Moltz [3] recently reported a role of the VNO in lordosis behavior of the female rat.

They removed the VNO and observed the depression in the incidence of lordosis behavior, although the ovarian cycle was not disrupted. These results, however, were based on a lordosis quotient: number of lordosis behavior displayed $/ 10$ mounts experienced $\times 100$, and the male was allowed to mount the female only 10 times.

The question addressed was whether the incidence of lordosis behavior in the female rat following removal of the VNO would be accelerated when received a large number of mounts.

In the present experiment, the lordosis behavior in the VNO-ablated female paired with a male was recorded on video camera.

Animals: Adult female and male rats of the Wistar-Imamichi strain raised in our colony were used in this experiment. They were kept under controlled conditions of temperature (22 $-26^{\circ} \mathrm{C}$ ) and lighting (light on 0600-1800).

They were allowed to take standard laboratory diet and tap water ad libitum.

Upon reaching 100-125 days of age, these females underwent either removal of the VNO (VOX, $\mathrm{n}=6$ ) or a sham surgical procedure (SHAM, $\mathrm{n}=6$ ), as detailed in Saito and Mennella [2].

Procedure: The estrous cycles of the rats were checked daily by vaginal smears from one week after operation, and proestrous females were used in the behavioral test after two consective 4-day cycles. They were individually placed with a single sexually active male in a semicircular arena (radius 40 , height $50 \mathrm{~cm}$ ) faced 

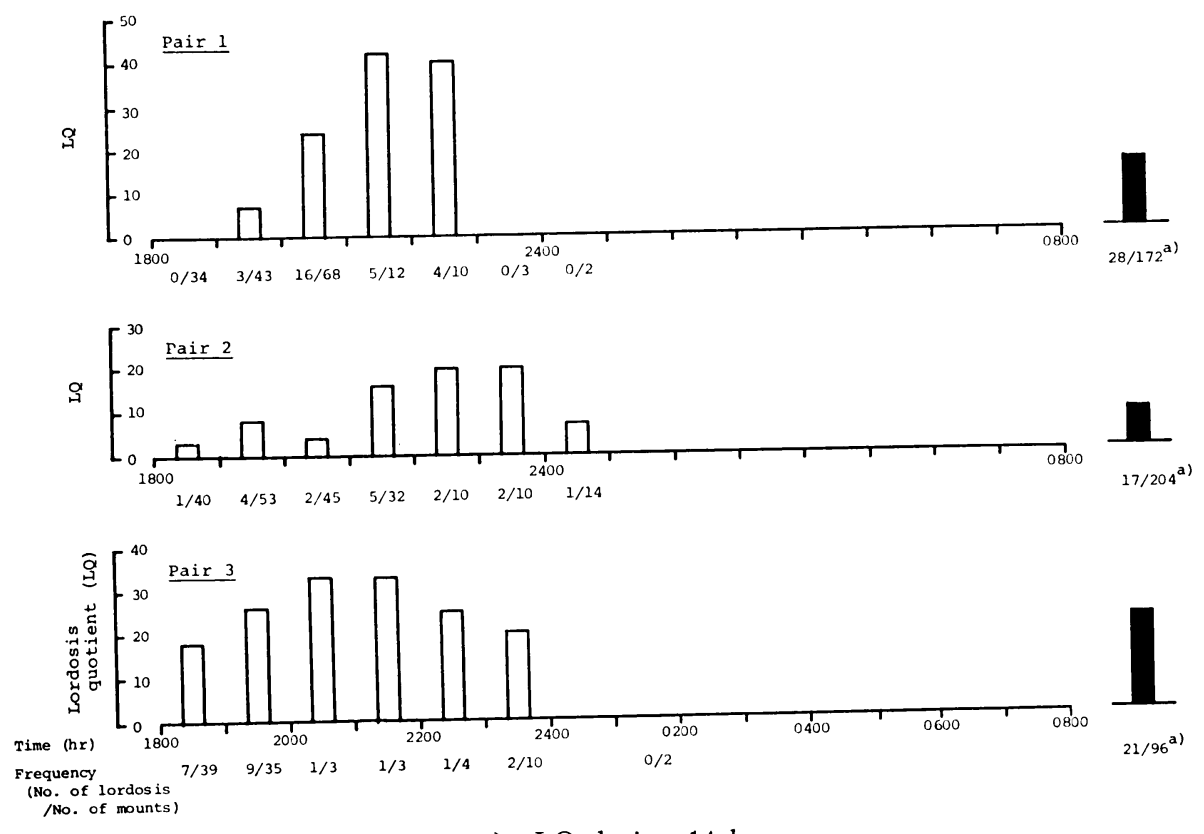

a); LQ during 14 hrs.

Fig. 1. Hourly lordosis quotient (LQ) in female rats following removal of the vomeronasal organ.

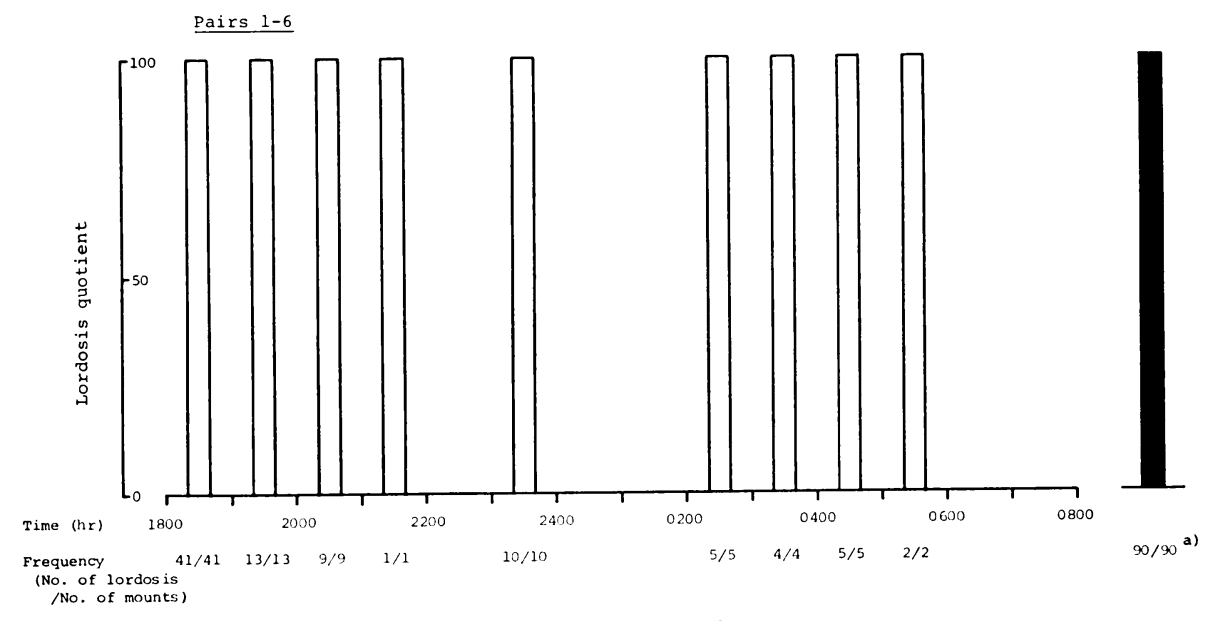

a); MLQ during $14 \mathrm{hrs}$.

Fig. 2. Hourly mean lordosis quotient (MLQ) in 6 sham-operated femal rats.

with Plexiglas and low-level red-light illumination. The lordosis behavior of each pair was recorded on video camera for $14 \mathrm{hrs}$ (1800 -0800) to calculate lordosis quotient. The females were checked whether they would be pregnant and whether they would give birth to youg.

Histology: At the end of the examination, each female was sacrificed for histological observations. The animal was perfused with $10 \%$ formalin and the head was decalcified in a formic acid solution, embedded in paraffin, sectioned at 40 $\mu \mathrm{m}$ and stained with hematoxylin and eosin.

Six VOX and 6 SHAM females showed a regular 4-day cycles after operation. Fig. 1 shows the incidence of lordosis behavior in 3 
females of the VOX group. The sexual behavior of each pair was observed until 0100 or $0200 \mathrm{hr}$ on estrus. The males showed active mounting behavior until 2100, 2200 and 2000 $\mathrm{hr}$ in pairs 1, 2 and 3, respectively. However, hourly lordosis quotients remain low in the range of 0 to 26 during these periods. When paired for $14 \mathrm{hrs}$, the females received 96 to 204 times of mounts and showed lordosis quotients of 16,8 and 22, respectively. Despite these low lordosis quotients, each female was impregnated and gave birth to viable young.

For reference, the mean incidence of lordosis behavior of six SHAM females is shown in Fig. 2. As was expected, these animals showed the highest lordosis quotient of 100 through the behavioral test.

These results indicate that the VNO is the essential receptor of chemosensory information to induce the lordosis hehavior in the rat.
Histological study revealed that the VNO had been removed from all VOX females used and was intact in all SHAM females.

\section{Acknowledgments}

The authors wish to express their thanks to Prof. Dr. H. Moltz, The University of Chicago, Chicago, IL 60637, U.S.A., and Dr. Y. Shirasu, The Institute of Environmental Toxicology, Kodaira, Tokyo 187, Japan, for their advices.

\section{References}

[1] Pfaff, D. W., and Sakuma, Y. (1979). J. Physiol., 288, 189-202.

[2] Saito, T. R., and Mennella, J. A. (1986). Exp. Anim., 35, 527-529.

[ 3 ] Saito, T. R., and Moltz, H. (1986). Physiol. Behav., 38, 81-87.

\title{
鋤鼻器剔出雌ラットに拈けるロードシス行動 の発現割合について
}

\author{
斎藤徹・外尾亮治*.今道友則*
}

\author{
(財) 残留農薬研究所
}

* (財 動物繁殖研究所

\begin{abstract}
Wistar 今道系雌ラットの鉫鼻器を生後約 4 力月秢で 剔出した。術後, Smear の採取, 観察を行い, 発情前期 像を示したラットと交尾能力を持った雄ラットとの同居 を午後 6 時より翌朝の 8 時までの 14 時間行った（照明条 件：午後 6 時消灯, 午前 6 時点灯)。性行動の観察には ビデオカメラを利用した。雌の性行動の発現率には, 口
\end{abstract}

ードシス商（ロードシス行動の回数/マウント回数 $\times 100 ）$ を用いた。鉫鼻器剔出雌ラットのロードシス商は観察期 間中, 8〜22 であり, 偽手術の発現率 (100) と比較し, 非常に低い值を示した。しかし，低いロードシス商にも かかわらず, 錐鼻器剔出雌ラットは数回の射精を受け, 妊娠し, 出産に至った。 